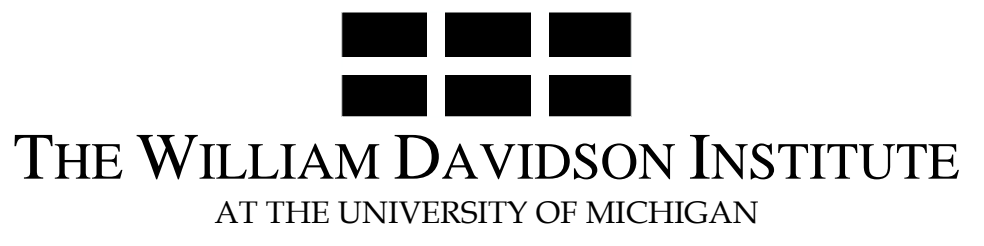

Crime Distribution \& Victim Behavior

During a Crime Wave

By: Rafael Di Tella, Sebastian Galiani
and Ernesto Schargrodsky

William Davidson Institute Working Paper Number 849

November 2006 


\title{
Crime Distribution and Victim Behavior during a Crime Wave
}

\author{
Rafael Di Tella \\ $H B S$
}

\author{
Sebastian Galiani \\ Washington University in \\ St. Louis
}

\author{
Ernesto Schargrodsky* \\ UTDT
}

November 13, 2006

\begin{abstract}
The study of how crime affects different income groups faces several difficulties. The first is that crime-avoiding activities vary across income groups. Thus, a lower victimization rate in one group may not reflect a lower burden of crime, but rather a higher investment in avoiding crime. A second difficulty is that, typically, only a small fraction of the population is victimized so that empirical tests often lack the statistical power to detect differences across groups. We take advantage of a dramatic increase in crime rates in Argentina during the late 1990s to document several interesting patterns. First, the increase in victimization experienced by the poor is larger than the increase endured by the rich. The difference appears large: low-income people have experienced increases in victimization rates that are almost 50 percent higher than those suffered by high-income people. Second, for home robberies, where the rich can protect themselves (by hiring private security, for example), we find significantly larger increases in victimization rates amongst the poor. In contrast, for robberies on the street, where the rich can only mimic the poor, we find similar increases in victimization for both income groups. Third, we document direct evidence on pecuniary and non-pecuniary protection activities by both the rich and poor, ranging from the avoidance of dark places to the hiring of private security. Fourth, we show the correlations between changes in protection and mimicking and changes in crime victimization. Fifth, we offer one possible way of using these estimates to explain the incidence of crime across income groups.
\end{abstract}

JEL: K42

Keywords: Victimization, income distribution, private security, victim adaptation.

\footnotetext{
* Rafael Di Tella, Harvard Business School, Boston, MA 02163, US, rditella@hbs.edu, Tel: (617) 4955048. Sebastian Galiani, Department of Economics, Washington University in St. Louis, Campus Box 1208, St Louis, MO 63130-4899, US, galiani@economics.wustl.edu. Ernesto Schargrodsky, Universidad Torcuato Di Tella, Saenz Valiente 1010, (1428) Capital Federal, Argentina, eschargr@utdt.edu, Tel: (5411) 4783-3112. We thank participants at various seminars for helpful comments, the IDB Poverty Reduction and Social Protection Network for financial support, and Maximiliano Appendino, Matias Cattaneo and Paulo Somaini for excellent research assistance.
} 


\section{Introduction}

Previous work on the economics of crime has found it hard to estimate the relationship between income and crime victimization. One important difficulty is that crime-avoiding activities vary across income groups. As Levitt (1999) explains:

“...the natural tendency is to calculate the extra burden borne by the poor as a result of higher crime victimization. Such a calculation, however, would ignore the fact that individuals distort their behavior in costly ways (for example, by moving to the suburbs, investing in security systems, or not going out after dark). Any measure of the burden of crime should incorporate not only the costs of those victimized, but also the investment made to avoid victimization. For example, if crime avoidance is a positive function of income (Cullen and Levitt (1999)), then ignoring costs of avoidance will understate the true crime-related burden felt by the rich (Levitt, 1999, p. 88).

Thus, a lower victimization rate in one group may not reflect a lower burden of crime, but rather a higher investment in avoiding crime. The data on crime avoiding activities required for a proper calculation, however, are not part of the official statistics collected by the police and are rare in victimization surveys. Another serious difficulty is that only a small fraction of the population is usually victimized, and there are no sharp changes in victimization rates, which make it hard to design tests with sufficient statistical power to detect differencial changes across income groups.

We tackle the question of how an increase in crime is distributed across income groups using a crime survey where people are asked about their victimization experience, crimeavoiding activities, and income levels. In normal times, such a strategy would be impractical. But Argentina experienced during the 1990s and in particular during the year 2001 a sharp increase in crime rates, giving salience to the problem of crime. Official statistics, for example, show that the main categories of crime more than doubled (at least) in Buenos Aires during the 1990's, in spite of a reduction in crime reporting rates. In a relatively short period of time, the main cities of the country experienced striking 
increases in crime, making crime either the main or one of the main concerns of the population according to opinion polls. Abundant anecdotal evidence suggests that this crime wave was accompanied by a significant growth in private security protection and other crime avoiding strategies.

Our survey confirms that there was a large, statistically significant increase in crime over the period of analysis. The total victimization rate, which stands for having been a victim of a crime at home or in the street, went up approximately 24 percentage points. We use this victimization survey to obtain several estimates of interest. First, significant differences are observed across income groups. The poor (i.e, those below our estimate of the median income in the sample) experience an increase in the total victimization rate of 28 percentage points, while the rich (i.e., those above the sample median) experience an increase of 19 percentage points. In other words, the poor have experienced increases in victimization rates that are almost 1.5 times larger than those experienced by highincome people.

We then study whether this could be explained by differential crime avoidance by the rich. One piece of indirect evidence is obtained by studying victimization categories where the cost of changes in behavior (i.e., adaptation) differs. For example, changing behavior to avoid street robbery (for example by avoiding dark places or by mimicking less attractive targets) costs less money than changing behavior to avoid home robbery (for example by hiring private security). ${ }^{1}$ An important finding is that robberies in the street, where the rich cannot do better than mimic the behavior of the poor, show similar increases in victimization for both income groups. For home robberies, where the rich can protect themselves with expensive protection devices, we find larger increases in victimization rates amongst the poor. The size of this differential impact is large. Early in the 1990's, rich individuals report victimization rates that are more than double those reported by the poor. But by 2001, high-income respondents report victimization rates at home that are smaller (in fact they are only 75 percent of those reported by the poor).

\footnotetext{
${ }^{1}$ The use of personal bodyguards on the street is exceptional.
} 
A third finding of the paper concerns direct evidence on crime-avoidance activities by high and low-income groups. For mimicking strategies, we consider avoiding the use of jewelry and avoiding dangerous places. For protection strategies, we consider the use of alarm and the hiring of private security. We cannot reject the hypothesis of broadly similar changes in mimicking across high and low income groups, but we estimate a significantly larger increase in protection activities by the rich.

Fourth, we then estimate the correlation between victim-adaptation measures and crime victimization in panel regressions. We find a negative correlation between individual private protection measures and home crime victimization rates, controlling for individual and period fixed effects as well as neighborhood specific-period effects . We also offer some tentative arguments that can be used in a causal interpretation.

Finally, the paper concludes with a short section illustrating one possible use of these estimates to construct an indicator of the burden of crime across income groups. We observe, for example, that street crime allows for mimicking and other low-cost forms of victim adaptation, and that street crime has evolved similarly for rich and poor. Thus, it appears safe to assume that the burden of street crime is similar for both groups under the assumption of negligible mimicking costs. For home robbery, the data paint a different picture. Consider a given increase in victimization at home. On the one hand, high and low income groups protect themselves at different rates. Interpreting our estimates of protection on home robbery as causal, we note that the rich are predicted to have avoided almost all of the crime increase (indeed, the difference between the predicted victimization rate and zero is not significant). We note that this is consistent with the observed dynamics of home victimization for the rich (which exhibits no detectable change). On the other hand, and again under a causal interpretation of our estimates, the poor are predicted to have avoided a small part of the increase in crime. We note that this is inconsistent with the observed dynamics of home victimization for the poor, which shows a large increase: the predicted rate of home robbery for the poor is less than half of what is actually observed. We conjecture that this is the result of a negative externality arising from the home protection of the rich. 
Previous empirical work in this area is not large. There is certainly some work pying considerable attention to analyzing how income distribution or unemployment rates are relate to crime levels. It is hard, however, to translate the results in these papers, often involving aggregate measures, into a differential effect across income groups from a given increase in crime. ${ }^{2}$ A more convincing approach relies on the use of relatively disaggregated data. Levitt (1999), for example, uses data on crime rates across Chicago neighborhoods as well as data from the US National Crime Victimization Survey over the period 1970-90 to study a similar set of issues. He finds that property crime in the United States became more concentrated among the poor by approximately 60 percent. In a related spirit, Gaviria and Pages (2002) study victimization rates for 17 countries in Latin America between 1996 and 1998 and present a simple model where potential victims have the possibility of protecting themselves. They show that crime in Latin America tends to affect mostly rich and middle class households living in larger cities. There is relatively little work on victim adaptation, although interesting recent work by Lott (1998) has explored the possibility that potential victims protect themselves through concealed handguns (see also Lott and Mustard, 1997 and Duggan, 2001), while Cullen and Levitt (1999) study urban flight as a response to high rates of city crime. A related issue is that criminals maye respond to victim adaptation, for example by switiching to to other areas or other crimes. Hesseling (1994) reviews the literature on crime displacement (see also Cornish and Clarke, 1987). Levitt (1999) explains several limitations of previous work, including those emerging from the lack of information on crime avoidance activities.

Section II briefly describes the theory that illustrates the effect of increases in victimization across income groups when victims can adapt. Section III describes our

\footnotetext{
${ }^{2}$ Levitt (1999) provides a partial survey, and cites systematic reviews of the literature by Land et al (1990) and Patterson (1991). While empirical work on the issue of private protection is rare, theoretical work includes Shavell (1991), de Meza and Gould (1992) and Koo and Png (1994). See also Becker (1965, 1968), Ehrlich (1973), Witte (1980), Freeman (1996), Tauchen, Witte and Griesinger (1994), Papps and Winkelman (2000), Fajnzylber, Lederman and Loayza (2000, 2002), Garcette (2001), Dal Bo and Dal Bo (2004), Mocan et al (2005), inter alia. Glaeser and Sacerdote (1999) discuss the high crime rates in cities, while Londono et al (2000) discuss property crime relative to violent crime in Latin America.
} 
data and empirical strategy. Section IV presents our basic set of results, while Section V concludes.

\section{A Theoretical Illustration of Crime with Victim-Adaptation}

When crime increases, high-income citizens can protect themselves through the acquisition of expensive alarms or the hiring of private security devices. If this occurs, it is possible that low-income households suffer the main increase in victimization. We illustrate these ideas using a simple, one-shot game.

Start by assuming a continuum of agents with indexed ability $x_{i}$ distributed following $G($.$) . There are two decisions: i) to work (and earn w_{i}=x_{i}$ ) or to become a criminal; and ii) to set up an (observable) security system at cost $c$, or do nothing in this regard. One simple way to derive equilibrium crime is to assume that a friction exists in the labor market, so that wages below $f$ cannot be paid legally. This means the fraction $G(f)$ become criminals to avoid starvation.

For simplicity, we assume that the security system is fully effective and that wealth is not observable, so that criminals distribute randomly among unprotected agents. ${ }^{3}$ Then, people set up a security system if

$$
w_{i}-c>w_{i}(1-p)
$$

where $p$ the probability of victimization is equal to

$$
p=\frac{G(f)}{G\left(w^{*}\right)},
$$

and where the cut-off $w^{*}$ is defined as

\footnotetext{
${ }^{3}$ The assumption of fully effective protection seems strong, but we note that private security booths are patently observable, while the main companies installing alarm systems also place a sticker on the main entrance with the legend "this house is fitted with an alarm system by $\mathrm{xx}$ " where $\mathrm{xx}$ is the name of the company. This is in contrast to the car protection system (Lo Jack) studied in Ayres and Levitt (1998).
} 


$$
\frac{G(f)}{G\left(w^{*}\right)} w^{*}=c,
$$

and where agents with $w_{i} \geq w^{*}$ hire security systems. ${ }^{4}$ For simplicity, we assume thieves do not hire private security and we rule out multiplicity assuming $G(w)$ is concave for $w>f$.

Note that when the predisposition for crime increases, for example because the friction $f$ becomes larger, the consumption of security systems increases (agents with lower $w_{i}$ now protect themselves). And because protection is a normal good (and assumed to be effective), increases in crime lead the distribution of crime to become concentrated on lower income groups. Indeed, the probability of victimization for the unprotected increases on two accounts. First, the total number of criminals increases. And second, the number of unprotected targets is lower as more citizens hire private security. The concentration of crime increases on the group of poor individuals is all a consequence of crime displacement taking place due to higher investment in protection. In summary, the model yields the following predictions:

- $\quad$ The use of private security devices increases with the number of criminals.

- The use of private security devices concentrates on rich households.

- $\quad$ The poor suffer the main burden of crime increases.

The predictions of this simple model can be compared to our data on the evolution of crime in Argentina during the 1990s. At a relatively low unemployment rate, crime was low. As unemployment rates soared in the mid 90's, the rich increasingly payed the costs of hiring private protection. This behavioral response allowed the rich to avoid victimization, so that subsequent increases in unemployment continued raising the crime levels experienced by the poor. Crime rises as a result of the increase in the number of criminals (due to, say, higher unemployment), but it concentrates disproportionally in

\footnotetext{
${ }^{4}$ Note that if the security system cost $c$ is too high nobody hires private security, as it may happen for street protection. Also note that we allow thieves to become victims themselves.
} 
poor neighborhoods as high-income neighborhoods hire private security devices (which constitutes a negative externality on the poor). ${ }^{5}$

\section{Data and Empirical Strategy}

\section{III.a. Design and Data Description}

\section{Design}

A household victimization survey is the main source of information for this study. ${ }^{6}$ The target population of the study was the population of the Buenos Aires Metropolitan Area. The questionnaire was performed to 200 households in the City of Buenos Aires and 200 households in the suburban Great Buenos Aires through telephone interviews. In addition, 100 street interviews were performed to people that declared not to have a home telephone line. The survey collected information on victimization events, crime reporting, behavioral responses to crime, consumption of private protection, possession of durable goods and assets, and demographic household information. Note that official crime statistics do not typically collect such data, so that their inadequacy (for the purposes of this paper) goes beyond the usual difficulties arising from victim underreporting or political manipulation.

Although the survey was cross-sectional, it asked households to report retrospective information for the entire decade (1990-2001). However, retrospective information is sometimes subject to recall bias. Thus, the survey was designed exploiting several techniques specially developed to minimize this nuisance. First, the information set was restricted to major crime events: armed robberies and forcible entry into homes. The restriction to major events significantly reduces typical recall bias of retrospection, which is mainly associated to "microscopic" events (see Aday, 1996, and Reuband, 1994). Moreover, we concentrate on whether the household has been victim of a crime during a

\footnotetext{
${ }^{5}$ Gaviria and Pages (2002) present a related model of crime protection, but without displacement. Dal Bo and Dal Bo (2004) analyze a general equilibrium model of appropriation which predicts a positive association between crime and inequality that can naturally be applied to study the changes during a period of economic reforms such as those occurred in Argentina during the 1990s. Fajnzylber et al (2002) document such a positive correlation.
} 
period of time, but not on the number of times this has occurred. We should expect that recall bias has a larger effect on the latter, than on the former. Additionally, the retrospective information was asked sacrifying precision about the exact year of occurrence of an event, but gaining confidence by considering longer time periods. Thus, the survey considered three periods: 1990-1994 (the first part of the decade with one-digit unemployment rates and strong growth), 1995-2000 (the period after the Tequila crisis with the unemployment rate around $15 \%$-after a peak of $18.3 \%$ - and a declining economy after 1998), and the final year of 2001 (with an unemployment rate of $18 \%$ that then reached $21.5 \%$ in early 2002, with the default of the external debt and the end of currency convertibility). Moreover, the survey used bounded recall procedures to reduce underreporting of crime events that took place in previous periods (see, among others, Aday, 1996; Sudman et al 1984). More importantly, our main question is which group has been mostly affected by the increase in crime levels. As this question refers to the relative changes in victimization rates rather than the levels, the results will not be affected by recall bias if this bias affects both groups (rich and poor) similarly.

A final data issue is that the measure of income levels is a delicate matter because some people decline to reveal their income in a survey. Income questions could be particularly sensitive in a survey about private security. Instead of asking directly about income, the survey addressed this problem by asking questions on education level, ocupation, and availability of cars, appliances (PC, air conditioner, and automatic washing machine), and credit cards, in order to infer income levels from these variables. The opinion poll company, following the methodology developed by Argentine Marketing Association (1998), provided us with an index of income level that collapses all the indicators of household education, ocupation, and wealth into a continuous variable. Appendix 1 shows the details of this methodology. We define a household as rich if its income index is equal or above the median in our sample, and poor otherwise.

\footnotetext{
${ }^{6}$ The survey was performed in 2002 by the opinion poll company Catterberg \& Asoc. for the IDB Poverty Reduction and Social Protection Network.
} 


\section{Data}

Our research strategy is based on exploiting the salience of crime in Buenos Aires after the sharp increases in crime during the second half of the 1990s and in particular during the year 2001. Table 1 shows that $10.2 \%$ of the households interviewed by the survey suffered a home robbery (forcible entry into their house) during 2001. This percentage was the same for the whole period $1995-2000$, and $7.9 \%$ for $1990-1994$. Only $43.1 \%$ of these crimes were reported to the police in 2001, but the figure was larger in the previous years $(45.1 \%$ for $1995-2000$, and $74.4 \%$ for $1990-1994)$. For robberies outside the home, $34.6 \%$ of the individuals in our sample declare that at least one member of the household has been robbed during 2001. This percentage was $27.5 \%$ for $1995-2000$, and $10.0 \%$ for 1990-1994, suggesting that there was a significant increase in victimization rates (note that the question refers to periods of different length). The reporting rate of this type of crime tends to be lower than for home robberies, but it is also decreasing $(36.8 \%$ for 2001, $46.7 \%$ for $1995-2000$, and $51.1 \%$ for $1990-1994)^{7}$

These reporting rates confirm that, because of victims' tendency to underreport, official figures underestimate crime levels. ${ }^{8}$ Indeed, this problem worsens during crime waves, because crime reporting falls as crime increases. Moreover, the rich are significantly more likely to report crimes at home than the poor, although there were no significant differences in the reporting of street crimes across income groups.

Consistent with this evidence of sharp crime increases, Table A in Appendix 2 shows a growing feeling of insecurity in the population. The exact question asks "In your neighborhood, would you say that insecurity with respect to one decade ago has increased a lot, some, a little, has not changed at all, or has decreased?" The answers show that $68.8 \%$ of individuals think that insecurity increased some or a lot over the previous decade. Less than $1 \%$ of respondents find that insecurity decreased.

\footnotetext{
${ }^{7}$ These crime and reporting rates are consistent with other victimization surveys performed in the Buenos Aires metropolitan area. For example, a survey performed by the Justice Ministry reports that $41 \%$ of the respondents declared to have suffered a crime during 1999, but only $29 \%$ of those crimes were reported to the police (Ministerio de Justicia, 2000).

${ }^{8}$ Soares (2004) shows that the positive links between crime and development arise because of increases in crime reporting.
} 
Our research strategy requires changes in crime of the magnitude observed in Argentina between 1990 and 2001 for two reasons. First, it gives us some confidence that crime has "salience" as an issue to individual respondents so that the information produced through the administration of surveys has reasonable accuracy and reliability. Second, it is statistically possible to detect differences across groups (in this case following income lines) without extremely large samples.

Finally, to provide some evidence on the potential presence of recall bias affecting our results we exploit two extra survey questions. The survey first asked the number of times a member of the household had been robbed on the street during the period 1990-94. At the very end of the questionnaire, the survey then re-asked the number of times a member of the household had been robbed on the street during 1990-92, and during 1993-94, something that allows us to control for the consistency of the responses. There is a high level of consistency among respondents. The correlation between the sum of the responses to these two final questions and the previous response for the whole period is 0.9). Additionally, note that our empirical strategy is based on comparisons across income groups, which will not be affected by recall bias as long as this bias is uncorrelated with income levels. The correlation between our income level index and the difference between the original report of crime and the ex-post report is very low (0.02).

\section{III.b. Empirical Strategy}

In this paper we test several propositions regarding the relationship between victimization and income. We first study differences in the change in crime rates across income groups. Specifically we test:

$$
\Delta \text { Crime }_{\text {rich }}=\Delta \text { Crime }_{\text {poor }}
$$

against the alternative hypothesis of different crime rates for the two groups, and where $\Delta$ Crime $_{\text {group }}$ denotes the change in the crime rate for group=rich, poor from 1990 to 2001 considering the three sub periods 1990-94, 1995-2000 and 2001. Given that the periods 
have differing lengths the meaning of having the value of 0.1 (which stands for having 10 percent of the respondents victimized) in two different periods means different things. This makes it transparent that we believe that historical victimization rates taken from memory must be taken with care when used to make absolute statements across periods, such as the amount of crime has increased (although it can partially be done). Instead, we are confident in making statements about differences across groups in a given period, where victimization rates are strictly comparable, and also in conducting difference-indifferences analysis which exploits the differential change in victimatization between groups, and for which the change in the length of periods, and hence the likelihood of the realization of the event of interest, is affected equally for rich and poor. ${ }^{9}$

Another test concerns differences in the way potential victims adapt across the two income groups. A variety of victim strategies are possible. First, victims may actively protect themselves in such a way that it is more costly for criminals to access the bounty and get away with it safely. A typical example is the hiring of a private security guard, but it also includes the use of alarms and locks. A second possibility is that potential victims may change their behavior in order to passively reduce the likelihood of suffering a crime. A typical example is the case of potential victims of crime who avoid certain high-risk activities (walking alone on the street versus walking in groups). Potential victims may also reduce the expected cost of crime by carrying less money or jewels, both because this reduces the cost of any given crime and also because the probability of suffering a crime is lower. In the latter case victim adaptation can take the form of mimicking, whereby members of some group resemble the potential victims of another group with a lower probability of suffering a crime. For example, carrying fewer jewels makes a rich individual (with lots of money in his wallet) resemble a poor individual (with a thin wallet), where the latter are less attractive to criminals.

\footnotetext{
${ }^{9}$ This is analogous to the widely conducted studies in education that exploit panel data of test scores, where the inherent difficulty of the exam changes from year to year. These analyses also assume that this potential problem is controlled by the inclusion of year fixed-effects in the regression equations. See, Lavy (2002), Galiani et al (2006), inter alia.
} 
As a first approach to testing for the existence of victim adaptation, we study different types of crime where some forms of adaptation are not possible. For example, it is extremely hard to use protection to reduce crime on the streets. Although some extremely rich individuals use bodyguards, this is absolutely exceptional in Argentina. The type of adaptation to reduce such crimes is likely to be cheap, such as walking on the part of the street where there is light, so it is likely to be used by both income groups. However, the use of security guards and alarms as protection for crimes against property (home) is more expensive and likely to be used more intensively by the rich. In other words, we test

$$
\Delta \text { CrimeType }_{\text {rich }} \quad=\quad \Delta \text { CrimeType }_{\text {poor }}
$$

where $\Delta$ Crime Type $_{\text {group }}$ denotes the change in the crime rate of type=street, home and for the group=rich, poor over the relevant time period. The expectation is that the change in street crime becomes similar for both groups when victims adapt. In contrast, since private protection is more likely to be purchased by the rich, we expect the change in home crime to be greater for the poor when victims adapt.

We complement this evidence with direct information on activities that denote adaptation.

$$
\Delta \text { Activity }_{\text {rich }}=\Delta \text { Activity }_{\text {poor }}
$$

where $\Delta$ Activity $_{\text {group }}$ denotes the change in the activity for the group=rich, poor over the relevant time period. The expectation is that the change in activities that involve protection at home (security guards and alarms), or a reduction in expected crime costs (avoid carrying jewels, or credit cards, and avoid dark and dangerous places) are more intensive for rich individuals.

The final empirical exercise of the paper is to estimate the effect of changes in behavior $\left(\Delta\right.$ Activity $\left._{\text {group }}\right)$ on crime victimization $\left(\Delta\right.$ CrimeType $\left._{\text {group }}\right)$. Although individual, period and neighborhood period effects are included, it should be noted that an obvious 
difficulty in estimating such a relationship is the possibility of reverse causality. Accordingly we explore some arguments that can be used in a causal interpretation of the estimates we present.

\section{Empirical Results}

\section{IV.a. Total Victimization Rates (at Home plus in the Street)}

Figure 1 shows that approximately 15 percent of our sample declares to have been the victim of crime (either in the street or at home) at least once during the period 1990-94. This goes up to almost 35 percent during 1995-2000 and to almost 40 percent during the year 2001. This survey evidence is consistent with the crime increase documented in official statistics and the media. The official statistics reveal that the number of criminal acts reported to the police in the city of Buenos Aires went up from 2,039 per 100,000 people to 6,633 in the year 2001, an increase of 225\%. Property crime for the same period went up from 1,685 per 100,000 to 4,687 , an increase of $178 \%$.

More interesting is Figure 2, where total crime is separated by income group using our index for income levels. The rich start the decade with double the victimization rate than the poor (22 percent versus 11 percent, a difference that is significant at the 1 percent level). By the year 2001, the rates had risen to approximately 40 percent and where statistically indistinguishable. Statistical tests are presented in the Table 2.

The evidence suggests that the poor have been the recipients of most of the increase in crime. The increase in crime for the poor has been approximately 1.5 times that suffered by the rich. The difference-in-differences change of the victimization rates between the first and last period of our study is significant at the 5 percent level. As a comparison note that, for the US, Levitt (1999) finds that property crime has become more concentrated on the poor over time. The magnitude of our finding is in line with his estimates. He reports that while in the 1970's high-income households were slightly more likely to be burglarized than low-income households, by the 1990's low income households were 60 percent more likely to be the victims of crime. 


\section{IV.b. Victimization Rates at Home and in the Street}

Figures 3 and 4 separately present the evolution of two different types of crime, at home or in the street, where victim adaptation is likely to differ by income group. Indeed, some of the possible behavioral responses at home involve costly actions (alarm, etc.) whereas those on the street appear to be cheaper (avoid the use of jewelry). Thus, a different response in the two crime categories would be indirect evidence of victim adaptation.

Figure 3 studies the evolution of victimization rates for street robberies across income groups. The difference-in-differences analysis for robberies suffered by household members outside the house is presented in Table 3. For the three periods, high-income households suffered a higher victimization rate than low-income families. The crosssectional difference seems significant (at the 10 percent level of statistical significance) for the three periods. Moreover, both groups have suffered a significant increase in crime levels. Difference-in-differences tests, however, are never statistically significant at conventional levels, suggesting that the evolution of victimization rates have not differed across income groups.

Figure 4 studies victimization at home, while the accompanying table (Table 4) presents the associated tests. For the period 1990-1994, high-income households suffered a home victimization rate that was more than double that observed by low-income families (11 percent versus 5 percent). After that period, low-income households suffered a significant increase in victimization likelihood, while high-income families show a non-significant decline. The cross-sectional difference becomes insignificant in those subsequent periods. Thus, the victimization rate of the low-income households caught up to the high-income rate during the decade. Importantly, the difference-in-differences tests show that the change in the victimization rate of the low-income group is significantly different from the change for the high-income households. 


\section{IV.c. Adaptation at Home and in the Street}

A possible explanation for these differing crime dynamics by income group is that victims adapt. Figures 5-8 with their corresponding tables present four possible forms of adaptation. The first two involve costly investments in self-protection devices (hiring private security and buying alarms) while the last two involve a change in behavior that reduces the exposure to crime. Figure 5 focuses on the hiring of private security guards, an industry that grew substantially during the 1990s in Argentina and that affects home robbery. The answers to our survey question reveal that few households hire private security in the early part of the decade ( 7 percent of the rich versus 2 percent of the poor). By the year 2001, the hiring of private security had grown 16 percentage points amongst the rich and 8 percentage points for the poor. The difference in these changes in protection is statistically significant at the 1 percent level.

A similar picture of differential adaptation emerges from studying data on installing alarms, a cheaper form of protection at home (see Figure 6 and the corresponding Table). Relatively few respondents declare to have alarms installed in the early part of the sample period (10 percent of the rich versus 2 percent of the poor). By the year 2001, 25 percent of the rich and 8 percent of the poor have alarms. The change for the rich (15 percentage points) is larger than the increase for the poor ( 6 percentage points) and the changes between groups are statistically different at conventional levels of significance.

There are only a limited variety of strategies that people can employ to avoid becoming a victim of a robbery outside their houses. ${ }^{10}$ We consider avoiding dark places and avoiding the use of jewels. Figure 7 shows that both income groups have adapted by avoiding dark places as crime rates increased. More than $60 \%$ of the interviewed people declare to avoid dark places by the year 2001. There do not appear to be differences in the adoption of this strategy between poor and rich individuals, as Table 7 confirms.

\footnotetext{
${ }^{10}$ In the sample, 173 households declared that one of its members has been robbed outside the house during 2001. Those robberies took place on the street (125), in a car or public transportation (27), at work (3), in a shop or restaurant (15), at a bank or ATM (2) and other places (1).
} 
We have a second measure of adaptation on the street, namely avoid using jewels. Early in the sample period only 11 percent of the sample declared avoiding the use of jewels, a rate that is similar across income groups (although presumably the stock of jewels is larger amongst the rich). By the year 2001, 47 percent of the rich, and 37 percent of the poor declare to purposely avoid using jewels. The difference for the two groups is significant and, more importantly, the differences across income groups in the change in Avoid using Jewels are significant.

An alternative explanation for the differing crime dynamics by income group is that public officials might have biases against the poor in the provision of police services (see World Bank, 2000). The evidence, however, is not consistent with this hypothesis. First note that in Argentina, public police provision is not decentralized at the county level. Although the police told us that they purposely avoid cross sectional differences, ${ }^{11}$ it is still possible that political economy considerations (but not directly based on local tax collection) can lead to more intense public police deterrence in rich neighborhoods. ${ }^{12}$ However, note that such political economy aspects would explain the observed crime dynamics only if the differential deployment of police on rich versus poor areas changes over time. The survey also allows to explore the presence of differential public police provision, as it included information on police protection by asking at which frequency police walks or drives in front of people's houses. Table B in Appendix 2 presents the survey responses on public police protection which reveal no differences in the treatment and protection that the poor receive from the police relative to the rich.

\section{IV.d. The Impact of Victim Adaptation on Home Robbery}

Our data allows us to estimate correlations between the adoption of protection measures and victimization at home. Table 9 presents the results for having private security and having an alarm. All regressions include household fixed effects, and two estimates are

\footnotetext{
${ }^{11}$ We conducted a series of interviews with key informants, including several officials at the Security Ministry, the chief of the Federal Police during part of the 1990's, a former federal judge, a former federal prosecutor, amongst others.

${ }^{12}$ Garcette (2001) studies how crime victimization is distributed across income groups. He finds that crime victimization inequality increases in the income of the pivotal voter who sets the level of expenditure on public protection.
} 
reported for each protection device, one that controls for period fixed effects and one that controls for zone of residence-period fixed effects. In order to conduct this analysis we divide the Buenos Aires metropolitan area into seven zones of residence. The correlation is negative and significant. Both protective devices appear to reduce the likelihood of victimization at home in a given period of time. When entered together in the regression, private security appears to be $20 \%$ more effective than the use of alarms, but the difference is not significant at conventional levels. The last two columns produces the same results aggregating the two measures of home protection into to an index of security devices at home -i.e., the average value of the private security and alarm dummy variables. $^{13}$

Obviously, caution must be exerted when giving these correlations a causal interpretation. ${ }^{14}$ However, we note that the obvious sources of confounding effects are controlled for in the models we estimate. One potentially serious issue in relating the adoption of protection measures and victimization is that some people are both more likely to be victimized and also more likely to use security devices irrespective of the causal effect of the latter on the former. This problem, however, does not interfere with our estimates because we are including individual fixed effects in our models. We also believe that our estimates do not reflect a tendency for people to protect themselves in the presence of a crime wave because we are including period fixed effects. Moreover, and perhaps most importantly, the inclusion of zone of residence-period fixed effects also controls for the possibility that our estimates are biased-downward because of a tendency

\footnotetext{
${ }^{13}$ An alternative specification following the approach in the literature on technological horizontal spillovers (for a recent example see Smarzynska Javorcik (2004) and the references cited therein) exploits differences in average protection across our 7 zones. Accordingly, we added to our baseline model (column 7 of Table 9) the average level of protection of the rich by zone of residence interacted with a dummy that equals one if the household is classified as rich. The coefficient on the Aggregate Level of Security Devices at Home (which is simply the average for the zone) is negative, although only significant at the 10 percent level. The coefficient on Index of Security Devices at Home is still negative and significant. Indeed, its size is very similar to that reported in the corresponding regression in Table 9, column (7).

${ }^{14}$ For the causal effect of the introduction of fixed and observable police protection, a technology that resembles private security protection, see Di Tella and Schargrodsky (2004). They also discuss potential crime displacement induced by observable security guards, whereas Ayres and Levitt (1998) show positive externalities from the use of unobservable protection devices.
} 
for people who live in areas where there is a particularly large increase in crime to protect themselves. $^{15}$

Table 10 presents some further evidence that is relevant to provide our estimates with a causal interpretation, by investigating whether exposure to crime in previous periods predicts the adoption of security devices. The negative and insignificant coefficient does not suggest a reverse causality.

\section{IV.e. One Possible Calculation for the Burden of Crime (using Home Robbery)}

These estimates can be used to approximate the burden of crime suffered by the different groups. Indeed, it is possible to start with the estimated model in Column 7 of Table 9 and note that in this estimated equation the 2001 period fixed effect is equal to 0.04 ( $t-$ value $=2.03$ ). This gives us a measure of the overall increase in home victimization for the period 1990-2001 in the absence of any adaptation by victims.

We first focus on the implications for the rich. Given that the increase in the Index of Security Devices at Home for the period for the high income group was in fact 0.154 , we can conclude (under a causal interpretation of our estimates in Table 9) that protection helped the rich reduce crime by $0.028\left(0.028=0.183^{*} 0.154\right)$ and hence avoid 70 percent of the exogenous increase in crime $(0.7=0.028 / 0.04)$. This means that the rich are predicted to have avoided almost all of the crime increase. A formal test of the hypothesis that the reduction in crime as a result of protection is in fact 0.04 is not rejected at conventional levels of statistical significance $[\mathrm{F}(1,996)=1.38]$. We note that this is consistent with the observed dynamics of home victimization for the rich: The change in home robbery between 1990 and 2001 for the rich is not statistically significant at conventional levels (see Table 4). Thus, the evidence is broadly consistent with the

\footnotetext{
${ }^{15}$ Strictly, this analysis is only correct for home victimization because the measures of adaptation refer to the stock (e.g., whether people use alarms or hire private security), whereas our measures of adaptation on the street refer to changes (e.g, to avoid using jewels, not the absolute amount of jewelry that people use). Such changes are not necessarily related to stocks (those that do not have jewels can only trivially "avoid using jewels"). In an attempt to conduct a similar analysis for street victimization, we regressed street victimization on the changes in avoiding using jewels and avoiding dark places, household fixed effects and period (or zone of residence-period) fixed effects. These changes were never statistically significant, neither when entered alone nor when both changes were included together.
} 
hypothesis that the rich homes avoided the Argentine crime wave by increasing their level of protection.

On the other hand, and again under a causal interpretation of our estimates, the poor are predicted to have avoided only a small part of the increase in crime. The increase in the Index of Security Devices at Home for the period for the poor was 0.065, so protection helped the poor reduce crime by $0.011\left(0.011=0.065^{*} 0.183\right)$ and hence avoid 27 percent of the shock in crime $(0.27=0.011 / 0.04)$. We note that the predicted increase of 0.029 $(=0.04-0.011)$ is inconsistent with the observed dynamics of home victimization for the poor because Home Robbery for the poor increases by 0.07 (see Table 4). In other words, the predicted rate of home robbery for the poor is less than half of what is actually observed.

We conjecture that this discrepancy is the result of a negative externality arising from home protection by the rich. Indeed, the excess of crime observed for the poor over the predicted rate is 0.041 , which is consistent with the rich avoiding all the increase in crime which gets diverted to the poor (we do not reject the null hypothesis of full displacement at conventional levels of statistical significance $[\mathrm{F}(1,966)=0.2]$. Of course, this is just one way to decompose the changes in crime in our sample. But it highlights the main message of our simple model, whereby after a large exogenous increase in crime, the rich protect themselves avoiding all the effect of crime while the poor receive more crime than otherwise as a result of the displacement or negative externality generated by the rich.

\section{Conclusions}

An important question in the literature on crime concerns the relative impact amongst the rich and poor of a given increase in crime. The observed victimization rates for the groups are insufficient to derive the differential welfare burden of crime because individuals change their behavior in costly ways in order to avoid crime. The extent of such investments to avoid crime is likely to differ across income groups. If the rich have 
more resources to invest in crime protection, ignoring victim adaptation will obscure the burden of crime suffered by the rich and the externalities they impose on the poor. In this paper we provide several elements that are relevant to evaluate these effects.

We take advantage of a dramatic increase in crime that took place in Argentina during the 1990s using a survey that asked individuals their victimization rates and their investment in crime avoidance, both at home and on the street. We obtain several findings of interest:

1. During the period leading up to the economic crisis of 2001, crime increased more for the poor than for the rich. The increase in the total victimization rate for the poor was 1.5 times the increase in total victimization observed for the rich.

2. Changes in victimization in the street were similar for both income groups. In contrast, the increase in victimization at home was larger for the poor than for the rich. Indeed whereas in the early part of the decade, victimization at home for the rich was significantly larger than for the poor, in the year 2001 they were similar (if anything it was somewhat larger for the poor). This pattern is suggestive of victim adaptation because the cost of adaptation is lower on the street relative to home.

3. Direct evidence on victim adaptation reveals a different pattern across income groups. The rich are significantly more likely to hire private security and to install alarms than the poor. Adaptation on the street presents a different picture. The rich and the poor report similar increases in the avoidance of dark places. The rich report a larger increase in the avoidance of using jewels (although we expect them to start out with a higher level of jewelry).

4. We report a negative correlation between victimization at home and the use of alarms or private security, even after controlling for household fixed effects, for period-fixed effects and for the interaction of zones and period-fixed effects. We 
also report that previous experience with victimization at home is not correlated with the adoption of security devices.

5. We illustrate one possible use of these measures to estimate how victims' behavior affects the distribution of the crime burden across income group. We observe that street crime has evolved similarly for rich and poor. Given that victim adaptation on the street (e.g. mimicking) is likely to be cheap, it appears safe to assume a similar burden of street crime for both groups. For victimization at home, and under a causal interpretation of our estimates, we note that the rich are predicted to have avoided almost all of the crime increase. This is indeed consistent with the observed dynamics of home victimization for the rich (which exhibits no detectable change). On the other hand, the poor are predicted to have avoided a small part of the increase in crime. This is inconsistent with the observed dynamics of home victimization for the poor, which exhibits a large increase. Indeed, the predicted rate of home robbery for the poor is less than half of what is actually observed, which is consistent with full crime displacement from the rich to the poor.

6. Given that our estimates show that the changes in behavior induced by higher crime rates differ across income groups, and that victimization evolves differently across income groups, it seems important to investigate further the extent to which victim adaptation to changed circumstances in the crime "market" involves a negative externality on one particular group. 


\section{Appendix 1: Computation of the Income Level Index following Argentine Marketing Association (1998)}

The Income Level index (IL) assigns a point average for each household according to three variables. The index can take values between 4 and 100 points. The variables and the maximum values are summarized in the following table:

\begin{tabular}{|l|c|}
\hline \multicolumn{1}{|c|}{ VARIABLE } & $\begin{array}{c}\text { MAXIMUM } \\
\text { POSSIBLE VALUE }\end{array}$ \\
\hline - Education & 32 \\
\hline - Occupation & 40 \\
\hline - Wealth & 14 \\
a. goods and services & 14 \\
b. automobile & 100 \\
\hline Total & \\
\hline
\end{tabular}

Assignment of Points for each variable

1. Educational level of the household head. The values vary from 0 to 32 points according to the following table:

\begin{tabular}{|l|c|}
\hline \multicolumn{1}{|c|}{ EDUCATIONAL LEVEL } & POINTS \\
\hline No studies & 0 \\
\hline Primary School Incomplete & 5 \\
\hline Primary School Complete & 9 \\
\hline High School Incomplete & 13 \\
\hline High School Complete & 17 \\
\hline Vocational School Incomplete & 19 \\
\hline University Incomplete & 22 \\
\hline Vocational School Complete & 27 \\
\hline University Complete & 31 \\
\hline Postgraduate Studies & 32 \\
\hline
\end{tabular}

2. Occupation of the household head. The assigned points range from 4 to 40 according to the following table: 


\begin{tabular}{|c|c|c|c|}
\hline NON-EMPLOYEE & POINTS & EMPLOYEE & POINTS \\
\hline Do Not Work & \multirow{3}{*}{20} & Domestic Employee & 7 \\
\hline \multirow[t]{2}{*}{ Asset Holder } & & Family Worker without Fixed Income & 13 \\
\hline & & Non-Qualified Operator & 9 \\
\hline Self-Employed & & Qualified Operator & 17 \\
\hline Day Laborer & 4 & Technician / Foreman & 23 \\
\hline Other Non-Specialized job & 11 & Low Hierarchy Employee & \\
\hline Retailer without Employees & 18 & Public Sector & 12 \\
\hline Technician/Specialized worker & 24 & Private Sector & 17 \\
\hline Independent Professional & 30 & Middle Hierarchy Employee & \\
\hline \multirow[t]{2}{*}{ Other Self-Employed } & 17 & Public Sector & 19 \\
\hline & & Private Sector & 24 \\
\hline Employer & & High Hierarchy Employee & \\
\hline $1-5$ employees & 30 & Public Sector & 26 \\
\hline 6-20 employees & 36 & Private Sector & 30 \\
\hline 21 or more employees & 40 & Top Hierarchy Employee & \\
\hline & & Public Sector & 28 \\
\hline & & Private Sector & 37 \\
\hline
\end{tabular}

3. Wealth.

a. Goods and services. It measures the household capacity of accumulation of goods and services. The points are assigned according to the following table.

\begin{tabular}{|c|c|}
\hline $\begin{array}{c}\text { NuMBER OF THE FOLLOWING GOODS AND SERVICES } \\
\text { OWNED: PC, AIR CONDITIONER, CREDIT CARD AND } \\
\text { AUTOMATIC WASHING MACHINE }\end{array}$ & Points \\
\hline 0 & 0 \\
\hline 1 & 3 \\
\hline 2 & 7 \\
\hline 3 & 11 \\
\hline 4 & 14 \\
\hline
\end{tabular}

b. Automobile: the questions asked are concerned with (i) the number of automobiles owned, (ii) the branch, model and age of the first automobile, if applies, and (iii) the branch, model and age of the second automobile, if applies. Using this information, points are assigned separately for each car according to the following table.

\begin{tabular}{|l|c|c|c|}
\hline \multirow{2}{*}{\multicolumn{1}{|c|}{ AGE }} & \multicolumn{3}{|c|}{ BRANCH/MODEL } \\
\cline { 2 - 4 } & INFERIOR & MEDIUM & SUPERIOR \\
\hline 10 and more years & 1.5 & 2 & 2.75 \\
\hline Between 6 and 9 years & 3.5 & 6 & 6.5 \\
\hline Between 3 and 5 years & 5.5 & 7 & 8.5 \\
\hline Less than 2 years & 6.5 & 8 & 9.5 \\
\hline
\end{tabular}

Finally, the automobile point assignment must satisfy the following two rules: (1) if the final number of points is between 1 and 3, then zero is assigned to this category; and (2) if the sum of the points assigned for both cars together reaches 15 points or more, then 14 is assigned to this category. 


\section{Appendix 2:}

Table A - Perceived Insecurity

\begin{tabular}{|l|cc||}
\hline $\begin{array}{l}\text { In your neighborhood, would you say that insecurity } \\
\text { with respect to one decade ago has increased a lot, }\end{array}$ & Rich & Poor \\
some, a little, has not changed at all, or has decreased? & & \\
Increased a lot & $35.2 \%$ & $38.5 \%$ \\
Increased some & $29.7 \%$ & $27.1 \%$ \\
Increased a little & $13.7 \%$ & $8.2 \%$ \\
No change & $14.8 \%$ & $20.9 \%$ \\
Decreased & $0.4 \%$ & $1.2 \%$ \\
No answer & $6.2 \%$ & $4.1 \%$ \\
\hline
\end{tabular}

Table B - Frequency of Police Patrolling

\begin{tabular}{||c|r:c||}
\hline How often do the police usually patrol & Rich & Poor \\
your street? & $50.4 \%$ & $43.9 \%$ \\
Every day & $10.9 \%$ & $12.7 \%$ \\
Twice or three times a week & $5.5 \%$ & $6.1 \%$ \\
Once a week & $4.7 \%$ & $6.6 \%$ \\
At least once a month & $2.7 \%$ & $2.9 \%$ \\
Less than once a month & $11.7 \%$ & $16.0 \%$ \\
Never & $14.1 \%$ & $11.9 \%$ \\
No answer
\end{tabular}




\section{References:}

Aday, L. (1996), Designing and Conducting Health Surveys, Jossey-Bass.

Argentine Marketing Association (1998), "Indice de Nivel Socio Económico Argentino", mimeo.

Ayres, Ian and Steven Levitt (1998), "Measuring Positive Externalities from Unobservable Victim Precaution: An Empirical Analysis of Lojack", Quarterly Journal of Economics, 113 (1), 43-77.

Becker, Gary (1965), "A Theory of the Allocation of Time," Economic Journal, 75, 493517.

Becker, Gary (1968), "Crime and Punishment: An Economic Approach", Journal of Political Economy, 76 (2), 169-217.

Cornish, Derek and Ronald Clarke (1987), "Understanding Crime Displacement: An Application of Rational Choice Theory", Criminology, 25, 933-47.

Cullen, Julie, and Steven D. Levitt (1999), "Crime, Urban Flight, and the Consequences for Cities." Review of Economics and Statistics, 81 (2), 159-69.

de Meza, David and J. R. Gould (1992) "The Social Efficiency of Private Decisions to Enforce Property Rights", Journal of Political Economy, 100(3), 561-80.

Dal Bo, Ernesto and Pedro Dal Bo (2004), "Workers, Warriors and Criminals: Social Confict in General Equilibrium", mimeo.

Di Tella, Rafael and Ernesto Schargrodsky (2004), "Do Police Reduce Crime? Estimates Using the Allocation of Police Forces after a Terrorist Attack," American Economic Review, 94 (1), 115-133.

Duggan, Mark (2001), "More Guns, More Crime", Journal of Political Economy, 109, 1086-1114.

Ehrlich, Isaac (1973), "Participation in Illegitimate Activities: A Theoretical and Empirical Investigation", Journal of Political Economy, 81 (3), 521-65.

Fajnzylber Pablo, Daniel Lederman, and Norman Loayza (2000), "Crime and Victimization: An Economic Perspective," Economia (LACEA), 1(1), 219-302.

Fajnzylber, Pablo, Daniel Lederman and Norman Loayza (2002), "Inequality and Violent Crime", Journal of Law and Economics 45(1), 1-40.

Freeman, Richard (1996), "Why Do So Many Young American Men Commit Crimes and What Might We Do About It?", Journal of Economic Perspectives, 10 (1), 25-42.

Galiani Sebastian, Paul Gertler and Ernesto Schargrodsky (2006), "School Decentralization: Helping the Good Get Better, but Leaving the Poor Behind", mimeo UTDT.

Gaviria, Alejandro and Carmen Pages (2002), "Patterns of Crime Victimization in Latin American Cities," Journal of Development Economics, 67, 181-203.

Garcette, Nicolas (2001), "Income Inequality and Crime Protection", mimeo DELTA.

Glaeser, Edward, and Bruce Sacerdote (1999). "Why Is There More Crime in Cities?" Journal of Political Economy 107: S225-58.

Hesseling, Rene (1994), "Displacement: A Review of the Empirical Literature", in Ronald Clarke, ed., Crime Prevention Studies, III, 197-230.

Koo, Hui-Wen and Ivan Png (1994) "Private Security: Deterrent or Diversion?" International Review of Law and Economics, Vol. 14, 87-101 
Land, Kenneth, Patricia McCall, and Lawrence Cohen (1990), "Structural Covariates of Homicide Rates: Are There Any Invariances across Time and Space?" American Journal of Sociology, 95: 922-63.

Lavy, Victor (2002), "Evaluating the Effect of Teacher's Group Performance Incentives on Pupil Achievment", Journal of Political Economy 110, 1286-1317.

Levitt, Steven (1999), "The Changing Relationship between Income and Crime Victimization", FRBNY Economic Policy Review, 87-99.

Londono, J.L, Gaviria, A., Guerrero, R., (2000). Epidemologia y costos de la violencia en America Latina. Inter-American Development Bank, In press.

Lott, John and David Mustard (1997), "Crime, Deterrence, and Right-to-Carry Concealed Handguns", Journal of Legal Studies, 26 (1), 1-68.

Lott, John (1998), More Guns, Less Crime, The University of Chicago Press: London.

Mocan, Naci, Billups, Steve and Jody Overland (2005) "A Dynamic Model of Differential Human Capital and Criminal Activity", Economica, November, 72 $655-81$.

Ministerio de Justicia (2000), "Estudio de Victimización en Centros Urbanos de la Argentina", mimeo.

Patterson, E. Britt (1991), "Poverty, Income Inequality, and Community Crime Rates." Criminiology 29: 755-76.

Papps, K. and R. Winkelmann (2000), "Unemployment and Crime: New Evidence for an Old Question", New Zealand EconomicPapers, 34(1), 53-72.

Reuband, K (1994), "Reconstructing Social Change Through Retrospective Questions: Methodological Problems and Prospects", in Autobiographical Memory and the Validity of Retrospective Report, Schwartz, N. and S. Sudman (eds.), SpringerVerlag.

Shavell, Steven (1991) "Individual Precautions to Prevent Theft: Private vs Socially Optimal Behavior", International Review of Law and Economics, 11, 123-32.

Soares, Rodrigo (2004), "Development, Crime, and Punishment: Accounting for the International Differences in Crime Rates," Journal of Development Economics, 73 (1), 155-184.

Smarzynska Javorcik, Beata (2004), "Does Foreign Direct Investment Increase the Productivity of Domestic Firms? In search of Spillover Effects through Backward linkages", American Economic Review, 94 (3), 605-

Sudman, S., A. Finn and L. Lannon (1984), "The Use of Bounded Recall Procedures in Single Interviews", Public Opinion Quarterly, 48, 520-24.

Tauchen, Helen, Ann Dryden Witte, and Harriet Griesinger (1994), "Criminal Deterrence: Revisiting the Issue with a Birth Cohort", Review of Economics and Statistics, 76 (3), 399-412.

Witte, Ann (1980) "Estimating the Economic Model of Crime with Individual Data", Quarterly Journal of Economics, 94 (1), 155-67.

World Bank (2000), “Attacking Poverty,” World Development Report 2000/2001. 
Table 1 - Victimization and Reporting Rates

\begin{tabular}{|c|c|c|c|c|}
\hline & \multicolumn{2}{|c|}{ Home Robbery } & \multicolumn{2}{|c|}{ Street Robbery } \\
\hline & Victimization & Reporting & Victimization & Reporting \\
\hline 1990-1994 & 0.08 & 0.74 & 0.10 & 0.51 \\
\hline $1995-2000$ & 0.10 & 0.45 & 0.28 & 0.47 \\
\hline 2001 & 0.10 & 0.43 & 0.35 & 0.37 \\
\hline
\end{tabular}


Figure 1: Total Victimization Rates (Street or Home Robbery)

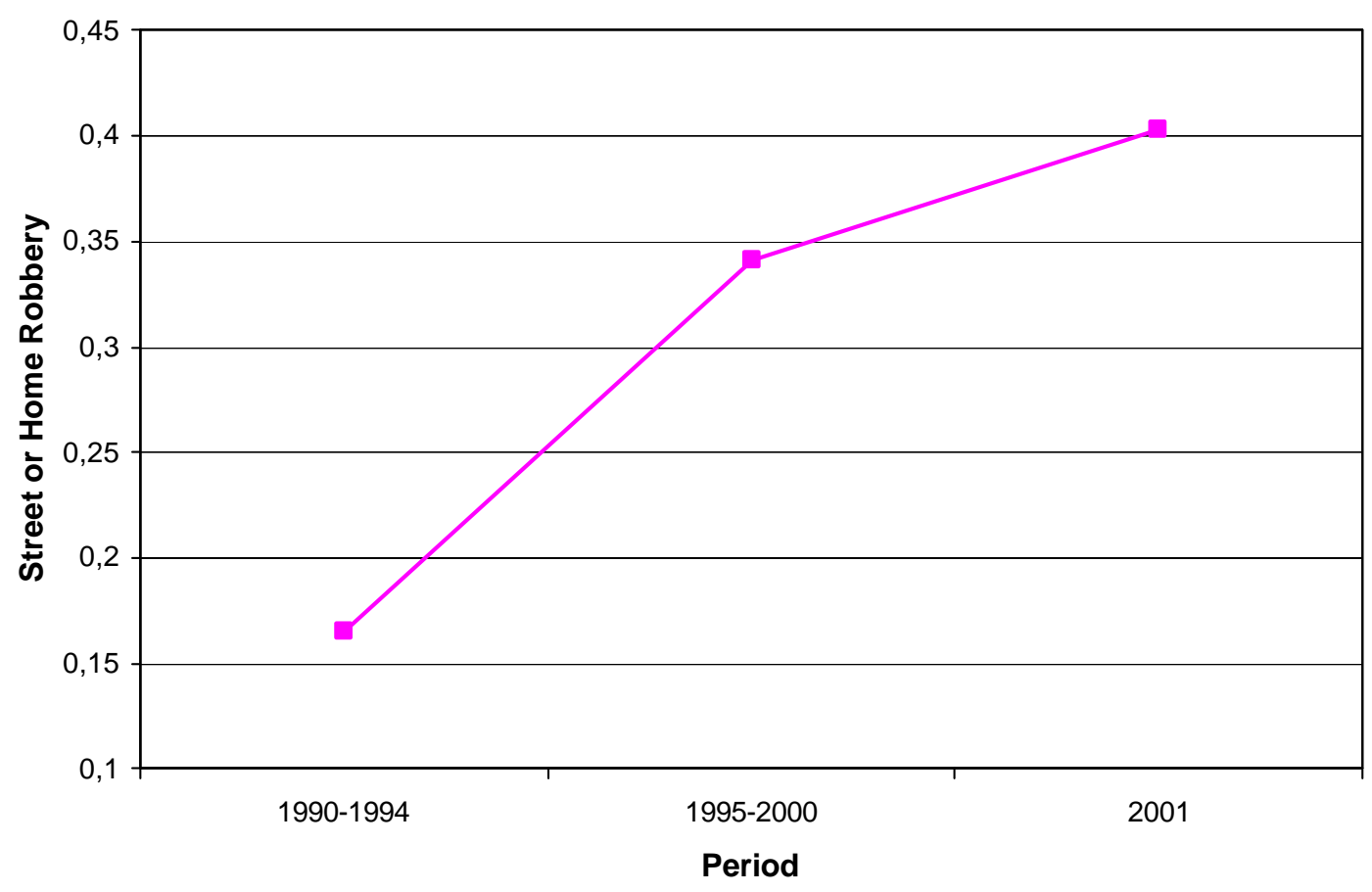




\section{Figure 2: Total Victimization Rates}

(Street or Home Robbery)

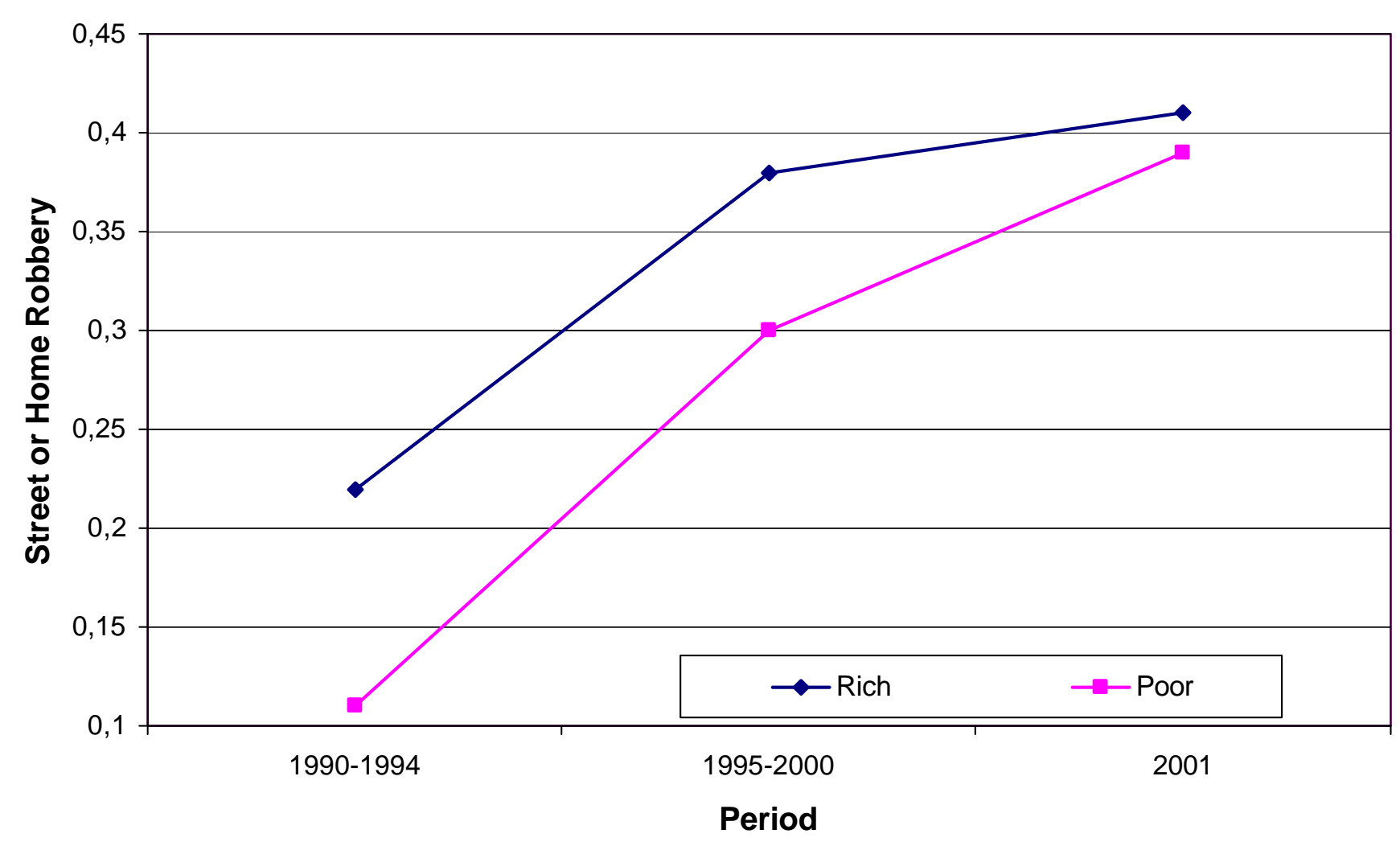

Table 2: Total Victimization Rates (Street or Home Robbery)

\begin{tabular}{|c|c|c|c|c|c|c|c|}
\hline \multirow{2}{*}{\multicolumn{2}{|c|}{ Home Robbery }} & \multirow[b]{2}{*}{$90-94$} & \multirow[b]{2}{*}{$95-00$} & \multirow[b]{2}{*}{2001} & [2001]-[90-94] & {$[95-00]-[90-94]$} & {$[2001]-[95-00]$} \\
\hline & & & & & $\begin{array}{l}\text { Diff-in-Diff } \\
\text { (S.E.) }\end{array}$ & $\begin{array}{l}\text { Diff-in-Diff } \\
\text { (S.E.) }\end{array}$ & $\begin{array}{c}\text { Diff-in-Diff } \\
\text { (S.E.) }\end{array}$ \\
\hline \multirow{2}{*}{\multicolumn{2}{|c|}{$\begin{array}{l}\text { Rich } \\
\text { Poor }\end{array}$}} & 0.22 & 0.38 & 0.41 & \multirow[b]{3}{*}{$\begin{array}{c}-0.11 * * \\
(0.05)\end{array}$} & \multirow[b]{3}{*}{$\begin{array}{l}-0.05 \\
(0.05)\end{array}$} & \multirow[b]{3}{*}{$\begin{array}{l}-0.07 \\
(0.06)\end{array}$} \\
\hline & & 0.11 & 0.30 & 0.39 & & & \\
\hline Rich-Poor & $\begin{array}{l}\text { Diff } \\
\text { S.E. }\end{array}$ & $\begin{array}{c}0.12 * * * \\
(0.03)\end{array}$ & $\begin{array}{c}0.09 * * \\
(0.04)\end{array}$ & $\begin{array}{c}0.02 \\
(0.04)\end{array}$ & & & \\
\hline
\end{tabular}

Note: Standard errors are in parentheses. * Significant at $10 \%$;* significant at $5 \%$; *** significant at $1 \%$. 
Figure 3: Street Robbery Victimization Rates

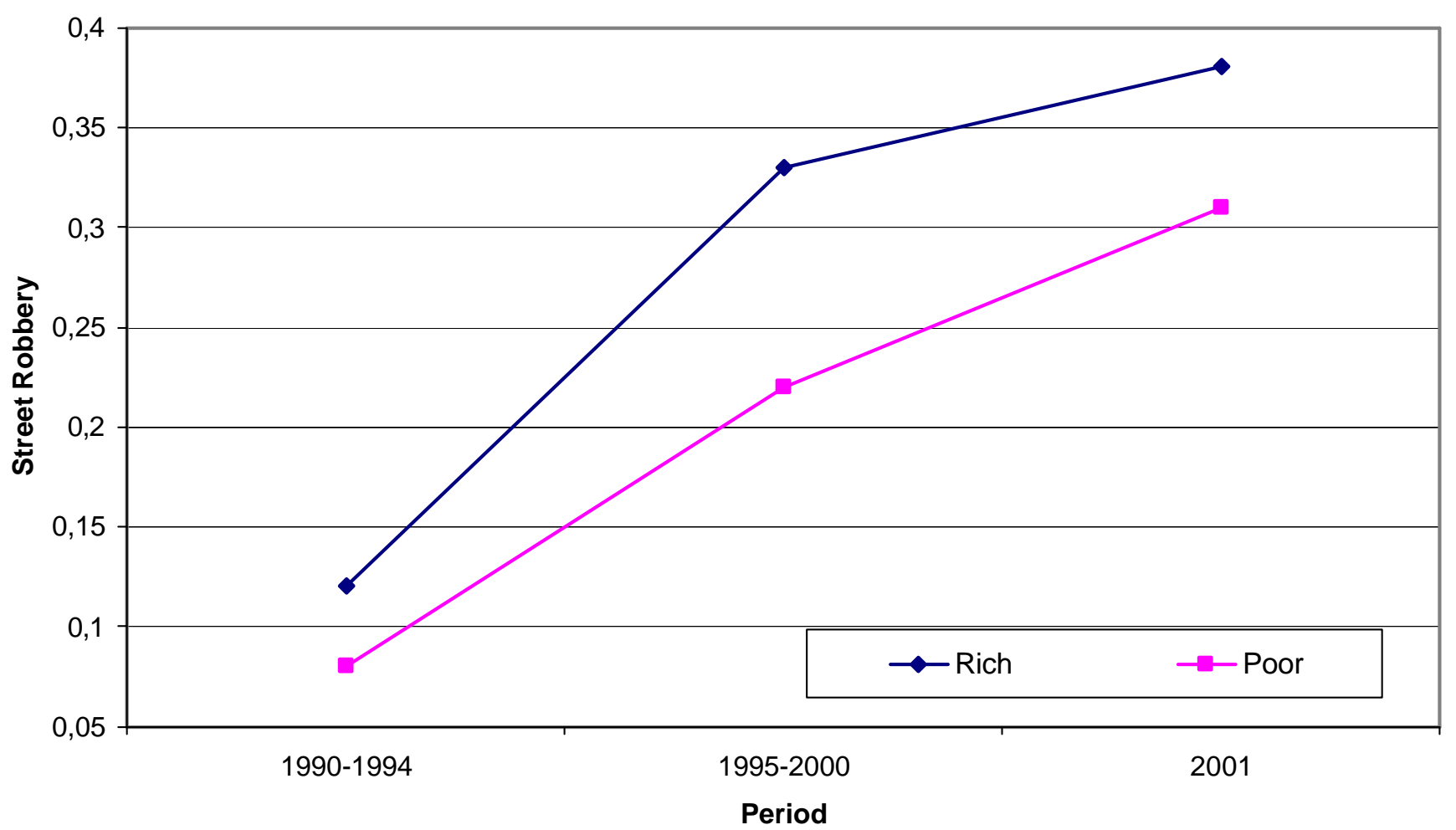

Table 3: Street Robbery Victimization Rates

\begin{tabular}{|c|c|c|c|c|c|c|c|}
\hline \multirow{2}{*}{\multicolumn{2}{|c|}{ Home Robbery }} & \multirow[b]{2}{*}{ 90-94 } & \multirow[b]{2}{*}{$95-00$} & \multirow[b]{2}{*}{2001} & [2001]-[90-94] & $\begin{array}{l}\text { [95-00]-[90-94] } \\
\end{array}$ & [2001]-[95-00] \\
\hline & & & & & $\begin{array}{l}\text { Diff-in-Diff } \\
\text { (S.E.) }\end{array}$ & $\begin{array}{l}\text { Diff-in-Diff } \\
\text { (S.E.) }\end{array}$ & $\begin{array}{c}\text { Diff-in-Diff } \\
\text { (S.E.) }\end{array}$ \\
\hline Rich & & 0.12 & 0.33 & 0.38 & & & \\
\hline Poor & & 0.08 & 0.22 & 0.31 & & & \\
\hline Rich-Poor & $\begin{array}{l}\text { Diff } \\
\text { S.E. }\end{array}$ & $\begin{array}{l}0.05^{*} \\
(0.03)\end{array}$ & $\begin{array}{c}0.11^{* * * *} \\
(0.04)\end{array}$ & $\begin{array}{l}0.08 * \\
(0.04)\end{array}$ & $\begin{array}{c}0.02 \\
(0.05)\end{array}$ & $\begin{array}{c}0.03 \\
(0.04)\end{array}$ & $\begin{array}{l}-0.04 \\
(0.06)\end{array}$ \\
\hline
\end{tabular}

Note: Standard errors are in parentheses. ${ }^{*}$ Significant at $10 \% ; * *$ significant at $5 \%$; *** significant at $1 \%$. 
Figure 4: Home Robbery Victimization Rates

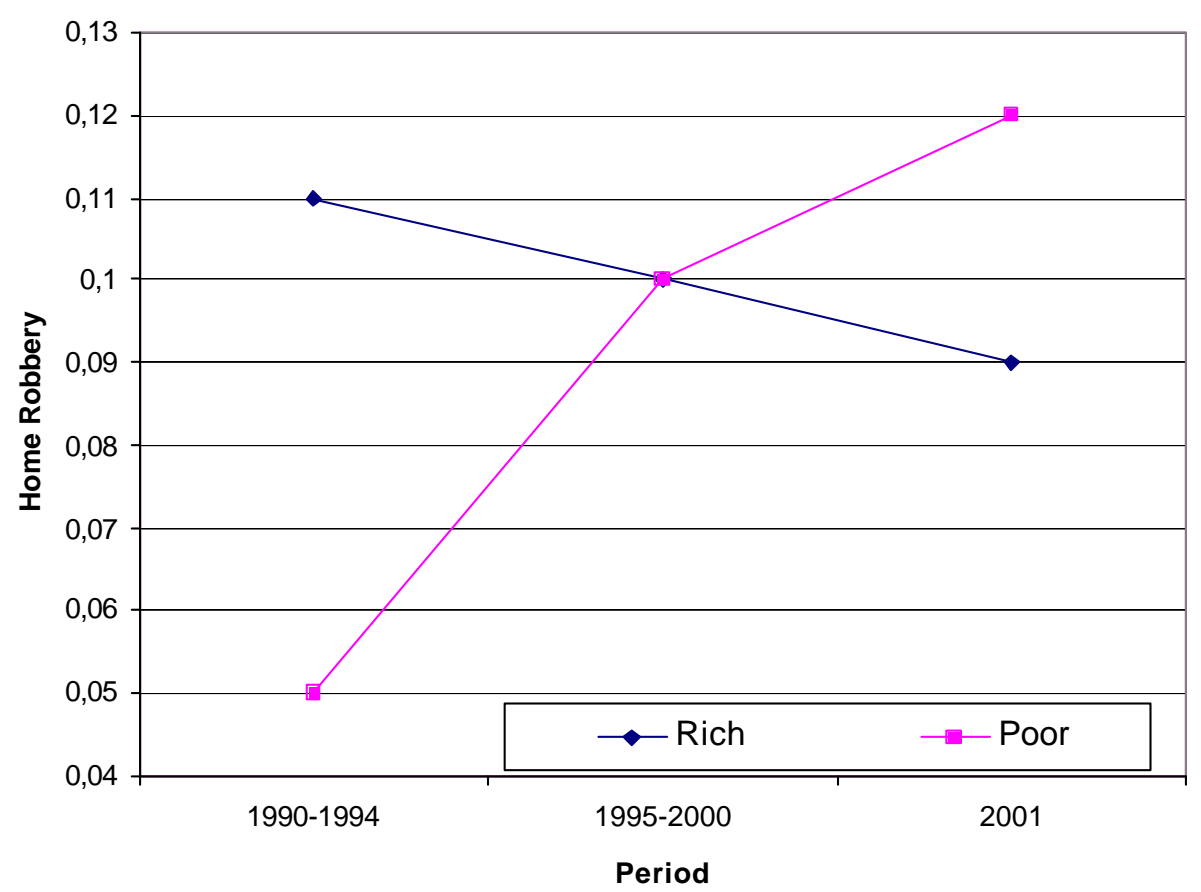

Table 4: Home Robbery Victimization Rates

\begin{tabular}{|c|c|c|c|c|c|c|c|}
\hline \multirow{2}{*}{\multicolumn{2}{|c|}{ Home Robbery }} & \multirow[b]{2}{*}{$90-94$} & \multirow[b]{2}{*}{$95-00$} & \multirow[b]{2}{*}{2001} & [2001]-[90-94] & [95-00]-[90-94] & [2001]-[95-00] \\
\hline & & & & & $\begin{array}{l}\text { Diff-in-Diff } \\
\text { (S.E.) }\end{array}$ & $\begin{array}{l}\text { Diff-in-Diff } \\
\text { (S.E.) }\end{array}$ & $\begin{array}{l}\text { Diff-in-Diff } \\
\text { (S.E.) }\end{array}$ \\
\hline Rich & & 0.11 & 0.10 & 0.09 & & & \\
\hline Poor & & 0.05 & 0.10 & 0.12 & & & \\
\hline Rich-Poor & $\begin{array}{l}\text { Diff } \\
\text { S.E. }\end{array}$ & $\begin{array}{c}0.06 * * * \\
(0.02)\end{array}$ & $\begin{array}{l}-0.00 \\
(0.03)\end{array}$ & $\begin{array}{l}-0.03 \\
(0.03)\end{array}$ & $\begin{array}{c}-0.09 * * * \\
(0.04)\end{array}$ & $\begin{array}{c}-0.06 * \\
(0.03)\end{array}$ & $\begin{array}{l}-0.03 \\
(0.04)\end{array}$ \\
\hline
\end{tabular}

Note: Standard errors are in parentheses. * Significant at $10 \%$; ** significant at $5 \%$; *** significant at $1 \%$. 


\section{Figure 5: Victim Adaptation at Home Hiring Private Security}

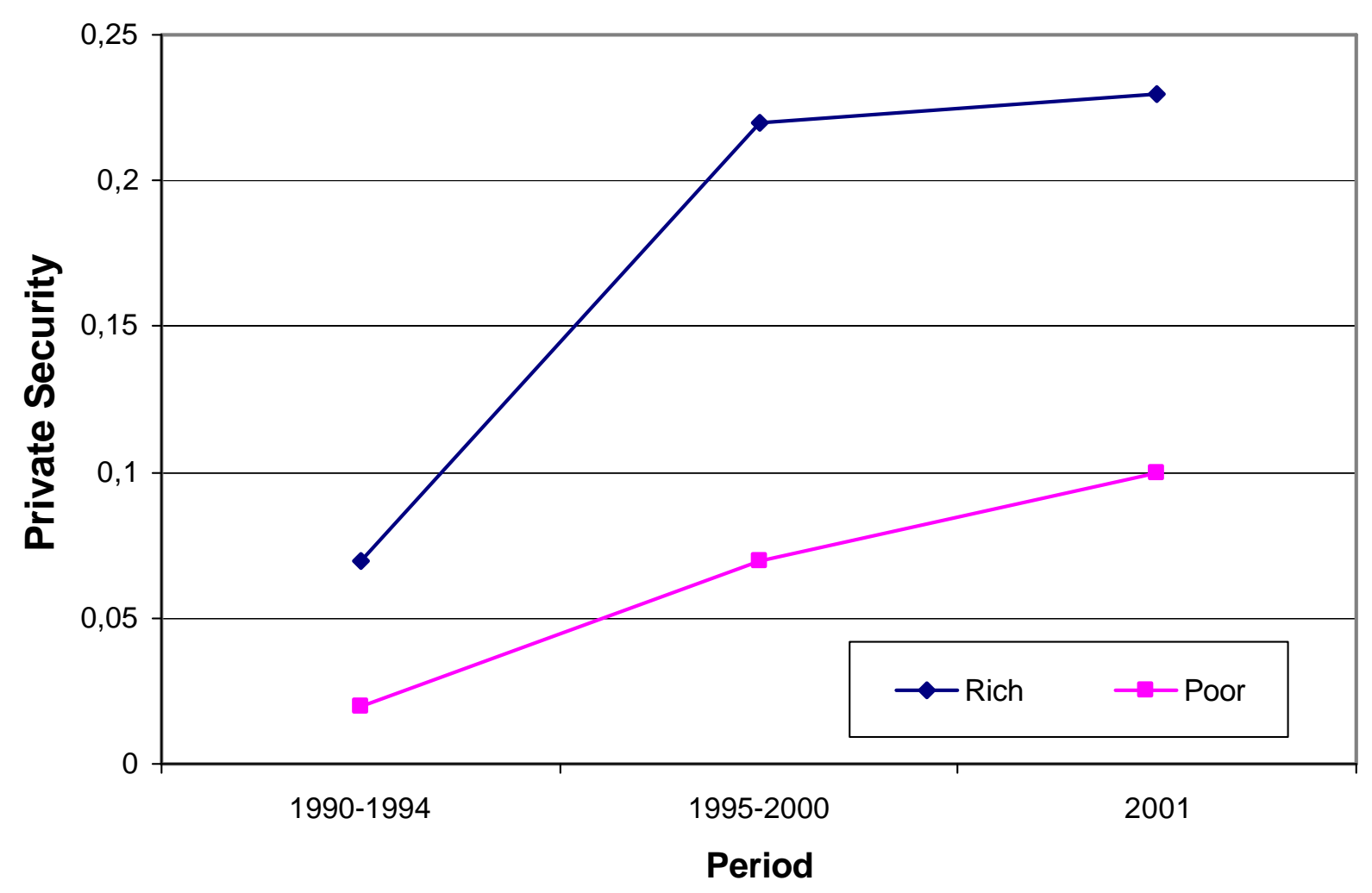

Table 5: Victim Adaptation at Home: Hiring Private Security

\begin{tabular}{|c|c|c|c|c|c|c|c|}
\hline \multirow{2}{*}{\multicolumn{2}{|c|}{ Home Robbery }} & \multirow[b]{2}{*}{$90-94$} & \multirow[b]{2}{*}{$95-00$} & \multirow[b]{2}{*}{2001} & [2001]-[90-94] & [95-00]-[90-94] & {$[2001]-[95-00]$} \\
\hline & & & & & $\begin{array}{l}\text { Diff-in-Diff } \\
\text { (S.E.) }\end{array}$ & $\begin{array}{l}\text { Diff-in-Diff } \\
\text { (S.E.) }\end{array}$ & $\begin{array}{l}\text { Diff-in-Diff } \\
\text { (S.E.) }\end{array}$ \\
\hline Rich & & 0.07 & 0.22 & 0.23 & & & \\
\hline Poor & & 0.02 & 0.07 & 0.10 & & & \\
\hline Rich-Poor & $\begin{array}{l}\text { Diff } \\
\text { S.E. }\end{array}$ & $\begin{array}{c}0.05 * * * \\
(0.02)\end{array}$ & $\begin{array}{c}0.15 * * * \\
(0.03)\end{array}$ & $\begin{array}{c}0.13 * * * \\
(0.03)\end{array}$ & $\begin{array}{c}0.08 * * * \\
(0.03)\end{array}$ & $\begin{array}{c}0.10 * * * \\
(0.03)\end{array}$ & $\begin{array}{l}-0.02 \\
(0.01)\end{array}$ \\
\hline
\end{tabular}

Note: Standard errors are in parentheses. * Significant at $10 \%$; ** significant at $5 \%$; *** significant at $1 \%$. 
Figure 6: Victim Adaptation at Home

Alarms

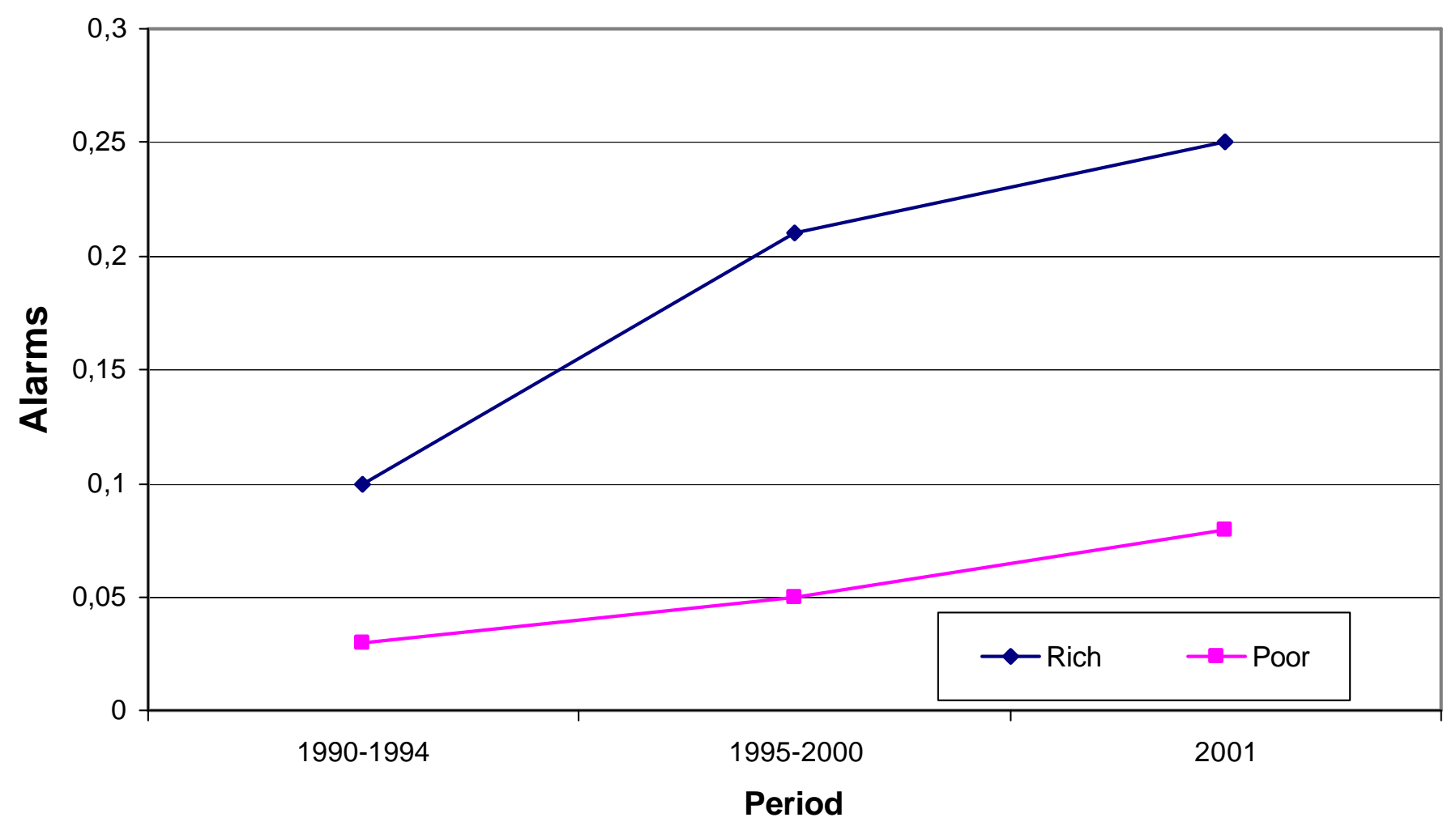

Table 6: Victim Adaptation at Home: Alarms

\begin{tabular}{|c|c|c|c|c|c|c|c|}
\hline \multirow{2}{*}{\multicolumn{2}{|c|}{ Home Robbery }} & \multirow[b]{2}{*}{$90-94$} & \multirow[b]{2}{*}{$95-00$} & \multirow[b]{2}{*}{2001} & [2001]-[90-94] & {$[95-00]-[90-94]$} & [2001]-[95-00] \\
\hline & & & & & $\begin{array}{l}\text { Diff-in-Diff } \\
\text { (S.E.) }\end{array}$ & $\begin{array}{c}\text { Diff-in-Diff } \\
\text { (S.E.) }\end{array}$ & $\begin{array}{c}\text { Diff-in-Diff } \\
\text { (S.E.) }\end{array}$ \\
\hline Rich & & 0.1 & 0.21 & 0.25 & & & \\
\hline Poor & & 0.02 & 0.05 & 0.08 & & & \\
\hline Rich-Poor & \begin{tabular}{|l} 
Diff \\
S.E.
\end{tabular} & $\begin{array}{c}0.07 * * * \\
(0.02)\end{array}$ & $\begin{array}{c}0.16^{* * * *} \\
(0.03)\end{array}$ & $\begin{array}{c}0.17 * * * \\
(0.03)\end{array}$ & $\begin{array}{c}0.09 * * * \\
(0.03) \\
\end{array}$ & $\begin{array}{c}0.09 * * * \\
(0.02)\end{array}$ & $\begin{array}{l}0.006 \\
(0.01)\end{array}$ \\
\hline
\end{tabular}

Note: Standard errors are in parentheses. ${ }^{*}$ Significant at $10 \%$; ** significant at $5 \%$; *** significant at $1 \%$. 


\section{Figure 7: Victim Adaptation on the Street Avoiding Dark Places}

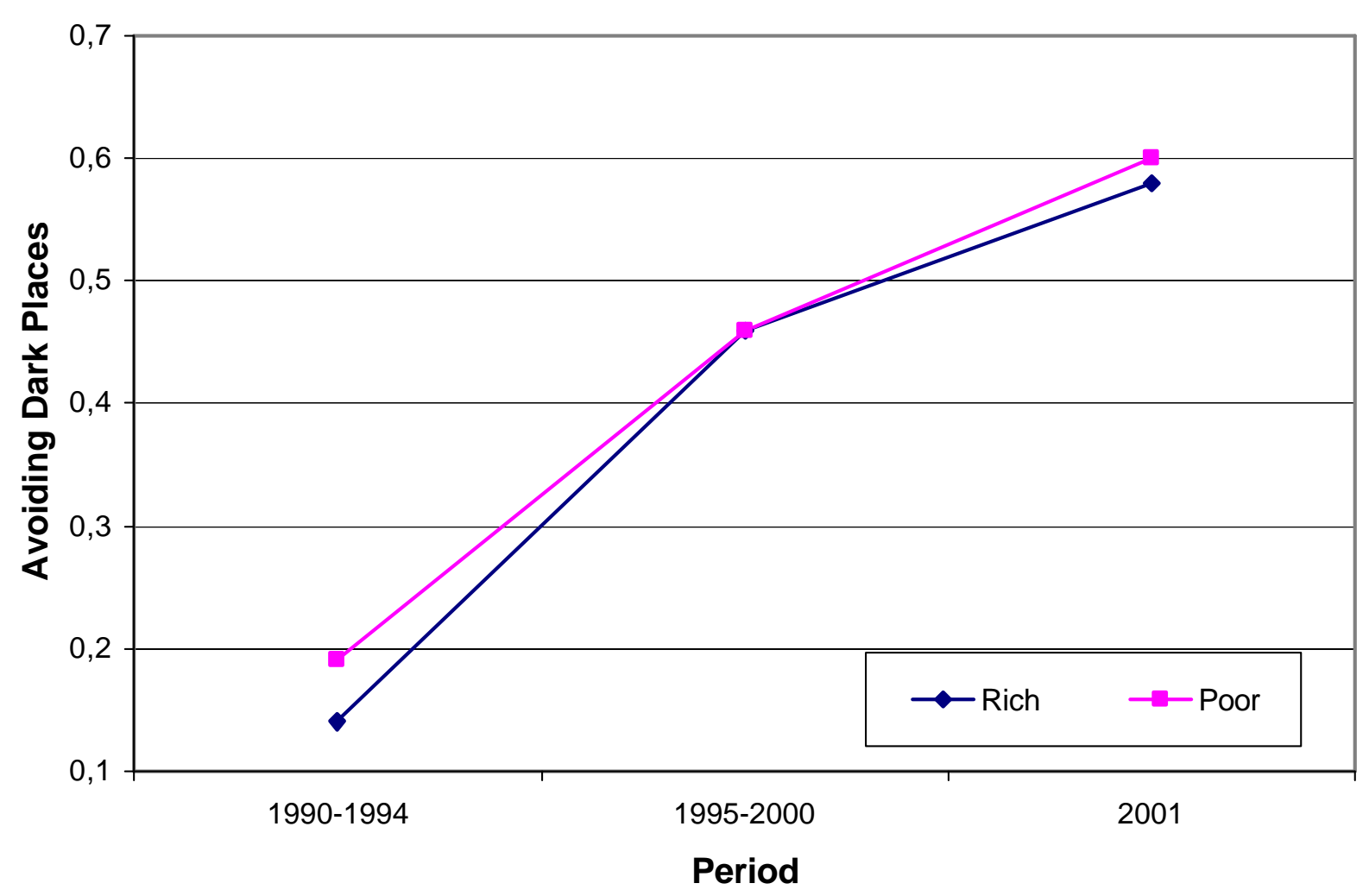

Table 7: Victim Adaptation on the Street: Avoiding Dark Places

\begin{tabular}{|c|c|c|c|c|c|c|c|}
\hline \multirow{2}{*}{\multicolumn{2}{|c|}{ Home Robbery }} & \multirow[b]{2}{*}{ 90-94 } & \multirow[b]{2}{*}{$95-00$} & \multirow[b]{2}{*}{2001} & [2001]-[90-94] & $\begin{array}{l}\text { [95-00]-[90-94] } \\
\end{array}$ & [2001]-[95-00] \\
\hline & & & & & $\begin{array}{l}\text { Diff-in-Diff } \\
\text { (S.E.) }\end{array}$ & $\begin{array}{l}\text { Diff-in-Diff } \\
\text { (S.E.) }\end{array}$ & $\begin{array}{l}\text { Diff-in-Diff } \\
\text { (S.E.) }\end{array}$ \\
\hline Rich & & 0.14 & 0.46 & 0.58 & & & \\
\hline Poor & & 0.19 & 0.46 & 0.60 & & & \\
\hline Rich-Poor & \begin{tabular}{|l} 
Diff \\
S.E.
\end{tabular} & $\begin{array}{c}-0.06 * \\
(0.03) \\
\end{array}$ & $\begin{array}{c}0.00 \\
(0.04) \\
\end{array}$ & $\begin{array}{l}-0.02 \\
(0.04)\end{array}$ & $\begin{array}{c}0.04 \\
(0.04) \\
\end{array}$ & $\begin{array}{c}0.06 \\
(0.04)\end{array}$ & $\begin{array}{l}-0.02 \\
(0.03) \\
\end{array}$ \\
\hline
\end{tabular}

Note: Standard errors are in parentheses. $*$ Significant at $10 \%$; ** significant at $5 \% ; * * *$ significant at $1 \%$. 
Figure 8: Victim Adaptation on the Street Avoiding Using Jewels

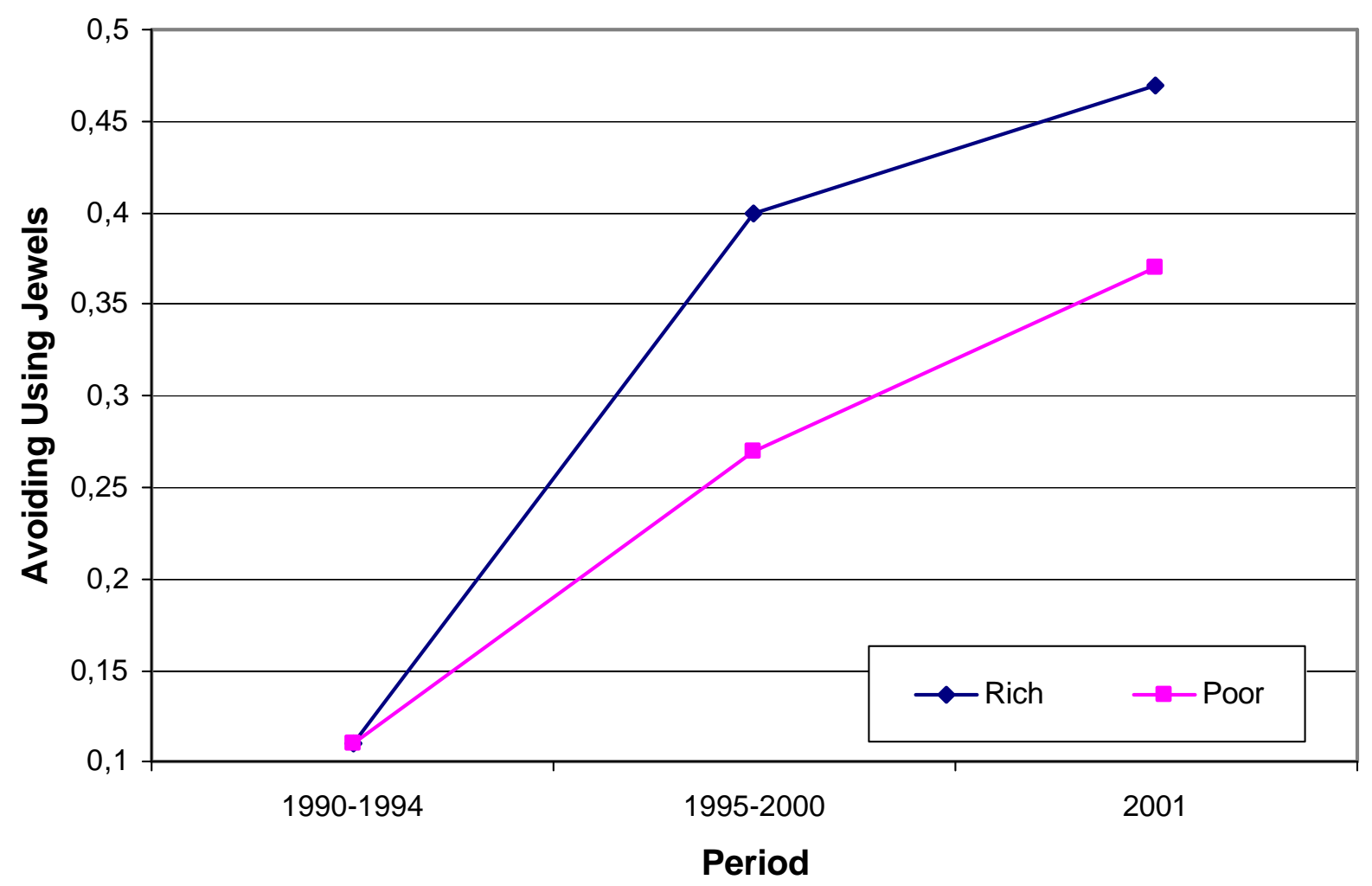

Table 8: Victim Adaptation on the Street: Avoiding Using Jewels

\begin{tabular}{|c|c|c|c|c|c|c|c|}
\hline \multirow{2}{*}{\multicolumn{2}{|c|}{ Home Robbery }} & \multirow[b]{2}{*}{$90-94$} & \multirow[b]{2}{*}{$95-00$} & \multirow[b]{2}{*}{2001} & {$[2001]-[90-94]$} & [95-00]-[90-94] & {$[2001]-[95-00]$} \\
\hline & & & & & $\begin{array}{l}\text { Diff-in-Diff } \\
\text { (S.E.) }\end{array}$ & $\begin{array}{l}\text { Diff-in-Diff } \\
\text { (S.E.) }\end{array}$ & $\begin{array}{l}\text { Diff-in-Diff } \\
\text { (S.E.) }\end{array}$ \\
\hline \multirow{2}{*}{\multicolumn{2}{|c|}{$\begin{array}{l}\text { Rich } \\
\text { Poor }\end{array}$}} & 0.11 & 0.40 & 0.47 & \multirow[b]{3}{*}{$\begin{array}{l}0.10 * * \\
(0.04)\end{array}$} & \multirow[b]{3}{*}{$\begin{array}{c}0.13^{* * * *} \\
(0.04)\end{array}$} & \multirow[b]{3}{*}{$\begin{array}{l}-0.03 \\
(0.03) \\
\end{array}$} \\
\hline & & 0.11 & 0.27 & 0.37 & & & \\
\hline Rich-Poor & $\begin{array}{l}\text { Diff } \\
\text { S.E. }\end{array}$ & $\begin{array}{c}0.01 \\
(0.03) \\
\end{array}$ & $\begin{array}{c}0.13 * * * \\
(0.04)\end{array}$ & $\begin{array}{l}0.11 * * \\
(0.04)\end{array}$ & & & \\
\hline
\end{tabular}

Note: Standard errors are in parentheses. ${ }^{*}$ Significant at $10 \%$; $* *$ significant at $5 \%$; *** significant at $1 \%$. 
Table 9: The Impact of Security Devices on Home Robbery

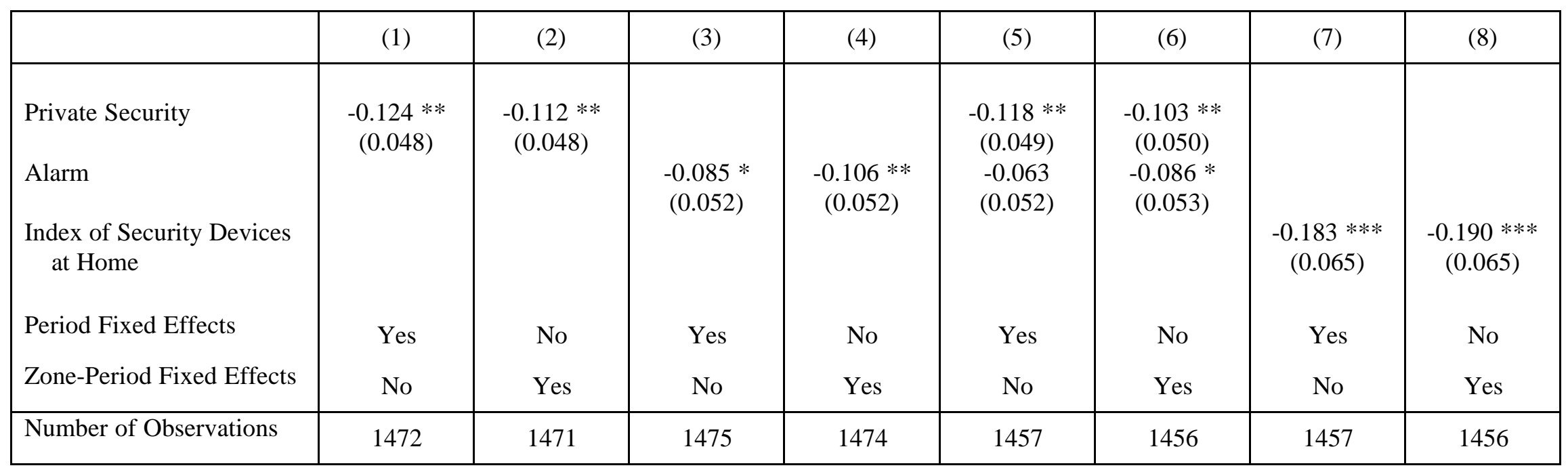

Notes: OLS regressions, standard errors in parentheses. All regressions include household fixed effects. The dependent variable is Victimization at Home. 
Table 10: The Impact of Lagged Crime on the Adquisition of Home Security Devices

\begin{tabular}{|l|c|c|}
\hline & $(1)$ & $(2)$ \\
\hline & -0.010 & -0.010 \\
Lagged Home Robbery & $(0.013)$ & $(0.014)$ \\
Period Fixed Effects & Yes & No \\
Zone-Period Fixed Effects & No & Yes \\
\hline Number of Observations & 970 & 970 \\
\hline
\end{tabular}

Notes: OLS regressions, standard errors in parentheses. All regressions include household fixed effects. The dependent variable is the Index of Security Devices at Home 


\section{DAVIDSON INSTITUTE WORKING PAPER SERIES - Most Recent Papers}

The entire Working Paper Series may be downloaded free of charge at: www.wdi.umich.edu

CURRENT AS OF 11/28/06

\begin{tabular}{|c|c|c|}
\hline Publication & Authors & Date \\
\hline No. 849: Crime Distribution \& Victim behavior During a Crime Wave & $\begin{array}{l}\text { Rafael Di Tella, Sebastian Galiani } \\
\text { and Ernesto Schargrodsky }\end{array}$ & Nov 2006 \\
\hline $\begin{array}{l}\text { No. 848: Real-Time Time-Varying Equilibrium Interest Rates: Evidence } \\
\text { on the Czech Republic }\end{array}$ & Roman Horváth & Oct 2006 \\
\hline $\begin{array}{l}\text { No. 847: Financial Accelerator Effects in the Balance Sheets of Czech } \\
\text { Firms }\end{array}$ & Roman Horváth & Nov 2006 \\
\hline $\begin{array}{l}\text { No. 846: Central Bank Interventions, Communication \& Interest Rate } \\
\text { Policy in Emerging European Economies }\end{array}$ & Balázs Égert & Nov 2006 \\
\hline $\begin{array}{l}\text { No. 845: On the Role of Absorptive Capacity: FDI Matters to } \\
\text { Growth }\end{array}$ & Yuko Kinishita and Chia-Hui Lu & Nov 2006 \\
\hline No. 844: Current Account Sustainability in Selected Transition Countries & Aleksander Aristovnik & Nov 2006 \\
\hline $\begin{array}{l}\text { No. 843: Policy, Economic Federalism \& Product Market Entry: The } \\
\text { Indian Experience }\end{array}$ & $\begin{array}{l}\text { Sumon Bhaumik, Shubhashis } \\
\text { Gangopadhyay and Shagun } \\
\text { Krishnan }\end{array}$ & Nov 2006 \\
\hline No. 842: Price Mobility of Locations & Konstantin Gluschenko & Oct 2006 \\
\hline $\begin{array}{l}\text { No. 841: The Role of Foreign Direct Investment in the Firm Selection } \\
\text { Process in a Host Country: Evidence from Slovenia }\end{array}$ & Katja Zajc Kejzar & Sept 2006 \\
\hline $\begin{array}{l}\text { No. 840: Family Ownership and Control in Large Firms: The Good, The } \\
\text { Bad, The Irrelevant - and Why? }\end{array}$ & Mike Peng and Yi Jiang & Oct 2006 \\
\hline No. 839: Price Linkages of Russian Regional Markets & Konstantin Gluschenko & Sept 2006 \\
\hline $\begin{array}{l}\text { No. 838: The Effect of Pre-Primary Education on Primary School } \\
\text { Performance }\end{array}$ & $\begin{array}{l}\text { Samuel Berlinski, Sebastian } \\
\text { Galiani and Paul Gertler }\end{array}$ & July 2006 \\
\hline $\begin{array}{l}\text { No. 837: Do Investors Value Insider Trading Laws? International } \\
\text { Evidence }\end{array}$ & Laura Beny & Aug 2006 \\
\hline No. 836: How corruption Hits People When They Are Down & Jennifer Hunt & Aug 2006 \\
\hline No. 835: Mirage at the Bottom of the Pyramid & Aneel Karnani & Aug 2006 \\
\hline $\begin{array}{l}\text { No. 834: Ownership concentration and firm performance: Evidence from } \\
\text { an emerging market }\end{array}$ & Irena Grosfeld & June 2006 \\
\hline $\begin{array}{l}\text { No. 833: Institutions, Networks and Entrepreneurship Development in } \\
\text { Russia: An Exploration }\end{array}$ & Ruta Aidis and Saul Estrin & June 2006 \\
\hline $\begin{array}{l}\text { No. 832: Long \& Short Run Linkages in CEE Stock Markets: } \\
\text { Implications for Portfolio Diversification \& Stock Market Integration }\end{array}$ & $\begin{array}{l}\text { Manolis Syllignakis and Georgios } \\
\text { Kouretas }\end{array}$ & July 2006 \\
\hline $\begin{array}{l}\text { No. 831: Inequality, Fiscal Capacity and the Political Regime } \\
\text { Lessons from the Post-Communist Transition }\end{array}$ & $\begin{array}{l}\text { Christopher J. Gerry and Tomasz } \\
\text { Mickiewicz }\end{array}$ & July 2006 \\
\hline $\begin{array}{l}\text { No. 830: Business Groups in Emerging Markets - } \\
\text { Financial Control and Sequential Investment }\end{array}$ & Christa Hainz & June 2006 \\
\hline $\begin{array}{l}\text { No. 829: Sophisticated Discipline in Nascent Deposit Markets: Evidence } \\
\text { from Post-Communist Russia }\end{array}$ & $\begin{array}{l}\text { Alexei Karas, William Pyle and } \\
\text { Koen Schoors }\end{array}$ & June 2006 \\
\hline $\begin{array}{l}\text { No. 828: Financial Deregulation and Financial Development, and } \\
\text { Subsequent Impact on Economic Growth in the CzechRepublic, Hungary } \\
\text { and Poland }\end{array}$ & Patricia McGrath & June 2006 \\
\hline $\begin{array}{l}\text { No. 827: The Determinants \& Excessiveness of Current AccountDeficits } \\
\text { in Eastern Europe \& the Former Soviet Union }\end{array}$ & Aleksander Aristovnik & June 2006 \\
\hline
\end{tabular}

